\title{
「撃剣」「剣術」から「剣道」への移行に関する史的考察
}

木下 秀明

\section{Historical study of the process of change from Kenjutsu to Kendo}

\author{
Hideaki Kinoshita
}

\begin{abstract}
This paper attempts to clarify the process of change from Gekiken and Kenjutsu to Kendo at the beginning of the 20th Century. The former two terms were widely used to mean swordsmanship with a bamboo sword. However, only the latter term is currently employed, despite the fact that it had been scarcely used at the time of the former two. At the end of the 19th Century, Gekiken was disliked by intellectuals because it marked a change from a real martial art to competition with a bamboo sword, and Kendo began to find favor instead of Gekiken even though the principle of Kendo had not been properly defined. In 1908, Shizuo Sakaguchi, a student, suggested that the concept of Kendo should consist of not only Kenjutsu training but also the mental discipline that is required for swordsmanship. However, his ideas did not gain immediate acceptance. In 1909, the Tokyo Higher Normal School changed the term Gekiken to Kendo, thus following the mainstream trend of adopting Kendo without any set idea of its content. Although in 1911 the Ministry of Education permitted Gekiken to be taught in secondary schools, the School intended to retain the term Kendo as a descriptor, and therefore it became necessary to properly define its content. Accordingly, Michiaki Nagai, the only professor of gymnastics at the School, emphasized the mental aspects of Kendo, as the suffix "-do" means "the way" for perfection of swordsmanship, as opposed to Gekiken and Kenjutsu, as the terms mean literally "hitting with" and "handling" a sword. The first special school for swordsmanship instructors was set up by the Ministry in 1911, and thereafter use of the term Kendo spread to all schools. The final aspect of this change of thought was the adoption of the term Budo instead of Bujutsu, meaning "martial art”, by the Great Japan Martial Virtue Association in 1919.
\end{abstract}

\section{Key words : Tokyo Higher Normal School, Great Japan Martial Virtue Association, Michiaki Nagai, Sakaguchi Shizuo, Nishikubo Hiromichi, Takano Sasaburō (Japan J. Phys. Educ. Hlth. Sport Sci. 51: 33-48, January, 2006)}

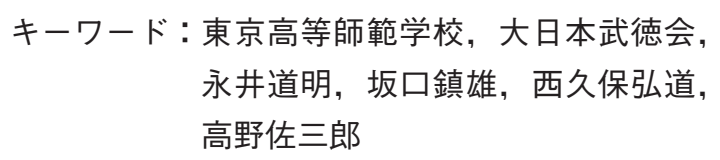

干 113-0023 東京都文京区向丘 2-31-2

連絡先 木下秀明
2-31-2, Mukogaoka, Bunkyo, Tokyo 113-0023

Correspondingauthor hideichi@tcn-catv.ne.jp 


\section{問題の提起}

今日では使用具に「道」をつけて「剣道」「弓 道」, それらの総称を「武道」と呼ぶ。しかし, 江戸時代には「武道」ではなく「武芸」「武術」 と呼び，武器に「術」をつけて「剣術」「弓術」 「馬術」と呼ぶのが一般的であった。その中で, 主に竹刀術に過ぎない狭義の「剣術」は，「撃剣」 とも呼ばれた。「撃剣」は, 竹刀術全盛となった 近代では「剣術」よりも一般的呼称となり，明治 25 (1892) 年改正「尋常師範学校の学科及其程度」 （原文カナ, 以下ひらがなに統一) の「説明」(表 1：2) 注1) 以降，文部省は，当初用いた「剣術」

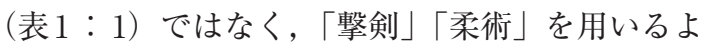
うになった。文部省が「撃剣」「柔術」を「剣道」 「柔道」と改称するのは, 大正 15 (1926) 年改正 「学校体操教授要目」(以下「要目」, 表 1 ：85) で，「武道」を用いるのは昭和 6（1931）年訓令 1 号からである.

このように，「撃剣」「剣術」から「剣道」への 移行は案外新しい.

今日の「剣道」は精神的価值を強調する（井上， 1986）が，精神重視は文部省の「撃剣」時代に始 まる。また，競技主体の竹刀術という点では， 「撃剣」と「剣道」に本質的相違はない。

何時から，何故，「撃剣」「剣術」を「剣道」と 呼ぶようになったのか。これが課題である。

中村 (1985, pp. 18-19，1994，2003）は，日 清・日露戦争後の「武術による攻撃精神の養成」 強調の時代に，大正 3 年警視庁警察練習所で「武 術」から「武道」への改称を提唱（表 $1 ： 74 ） し$ た西久保弘道が，大正 8 年大日本武徳会（以下 「武徳会」）副会長兼武術専門学校長に就任する （表 1：82）と，武徳会全規則中の「武術」が 「武道」と改められ (表 $1 ： 83$ ),「武術」専門学 校が「武道」専門学校と改称（表 $1 ： 84$ ) された ことを挙げる。

中村 (1985, pp. 275-281）が詳しいが, 武徳 会は, 明治 39 年制定の「武德流剣術形」（表 1 : 24）に替えて，大正元年に「大日本帝国剣道形」
を制定（表1：69）している。それ以前でも，明 治 40 年頃の体操科への武術採用論には「剣道」 が出て来る（木下，1965）。また，高野佐三郎は， 大正 4 年に「剣道」が使われるのは「最近二三十 年以来の事」（表 1：80）であると述べている.

したがって，「撃剣」を含む「(剣) 術」から 「(剣) 道」への移行は, 明治後半から大正中頃迄 の現象であると思われる。この間の「術」から 「道」への移行の実状を明らかにすることは，「剣 道」に代表される「武道」の近代化を把握する上 で，必須の作業と考える。

そこで, 本稿では, 最初に学校剣道部の名称を 指標として「撃剣」「剣術」から「剣道」への移 行の時期を把握し，つぎに表 1 を用いて，「術」 から「道」への移行に関する史実を展望し, 最後 に, 「(剣) 道」の提唱者と, その提唱理由の歴史 的意義を明らかにする。

\section{I 剣道部名称の移行時期}

武德会は, 日清講和条約締結の明治 28 年 4 月 17 日に，軍事面での国家興隆の気運を背景に国 粋的伝統の座をめざして設立された（表 $1 ： 5$ ). 剣道を中核とする武徳会は, 民間団体であるから， 学校剣道に直接関与できる立場ではなかったが, すでに「撃剣」「剣術」の名称で教科外活動とし て認知されていた中等教育以上の剣道に（表 1 : 2)，各地の武徳会支部が関与したことは充分考え られる。

表 2 は, 年度ごとの各『学校一覧』（不備・不 足の場合は学校史) に基づいて, 各学校毎に剣道 部（副科を含む）が「撃剣」「剣術」等を部の名 称としていた時期と，「剣道」部と呼称するよう になった時期とを図示した年表で，下部に各年度 毎の学校数を集計した. 調査対象には, 大学高専 を主体に若干の中等学校を加えた。配列は, 大学 高専 (公立優先), 師範学校, 中学校の順とした. 「撃剣」等は確認した最初と最後の年度を点線で, 「剣道」は確認した初出年度以降を棒線で, 制 定・改称年度を縦棒で示した。空白は，特定でき ない年度である。 


\section{1. 図示の概観}

学校間の改称年次の共通点を，学校の特性を考 慮して検討すると，つぎのことが分かる。

(1)所謂「天下の東大, 一高, 一中」の改称が, 伝統保守の老埔の暖策のように，著しく遅い。

(2)高等学校の改称時期には学校差が目立つ。高 校ごとの個性の反映であろうか.

(3)学習院（宮内省管轄）を含め, 私立の大学専 門学校は，何れも早い時点で改称している。

(4)東京高師の改称は, (3)の学校群に追随してい ると思われる (後述).

(5)師範系での最初の改称は東京高師である。こ れは，高師を総本山とする師範教育の宿命で，例 外はあるにせよ，府県師範が高師の改称をみてか ら動き出したことを意味する。

(6)「早稲田大学生の自称」を設けたのは，大学 認知の名称が「撃剣部」の段階で, 『早稲田学報』 に「剣道部」記事が掲載されている（早稲田大学 史編纂所，1981）からである.

(7)『学校一覧』等から特定できる部名び改称時 期は，6からみて，既成事実を追認した制度上の 時期である可能性が高い.

\section{2. 学校数の概観}

学校数の推移から，つぎのことが分かる。

(1)学校数は確認できた学校数に過ぎない.

(2)第四高等学校の明治 34 年の「剣道」への改 称は先駆的事例で，改称が継続的に始まるのは， 日露戦争 (明治 $37-38$ 年) の勝利が決定的とな ってからである。そして，殆どの学校が，大正 10 年頃までに「剣道」への改称を終わっている.

(3)日露戦争迄は殆どの学校が「撃剣」等を使用 していたが，「撃剣」の使用は日露戦争後から減 少し始めて, 大正 10 年頃には殆ど見られなくな っている.

(4)したがって，「撃剣」「剣術」から「剣道」へ の移行期は, 部名から判断すると, 日露戦争後か ら大正 10 年頃までの約 15 年間の長期にわたるこ とになる。

そこで，つぎに，この 15 年間の移行期に重点 を置き，この移行が顕在化するまでの前史を勘案
して整理した年表（表1）に基づいて，「術」か ら「道」への移行に関係ある史実を概観し，その 移行の過程で，理由を述べて「道」の使用を提唱 した人物を指摘する。

\section{II「術」から「道」への移行過程}

\section{1. 系列ごとの考察}

「術」から「道」への移行について, 表 1の系 列ごとに考察すると，以下のことが分かる.

(1)「撃剣」「剣術」の学校採用に消極的だった 文部省（表 1：1，9）に議会が圧力を掛け（表 $1 ： 17 ， 22 ， 31)$, 明治 44 年に学校採用となった 剣道の教材名「撃剣」は（表 $1 ： 57)$, 大正 15 年 改正要目（表1：85）まで使用された。したがっ て, 改正要目の「剣道」は, 学校現場の「術」か ら「道」への移行に追随する形での採用であるか ら，文部省は「術」から「道」への移行に消極的 であったと考えられる。

(2)嘉納校長のもとで「柔道」優先（表 $1 ： 3 ， 7$, 8，12）であった高師は，明治 39 年から「撃剣」 を正課に加え（表 $1 ： 21$ ），明治 $42-43$ 年に

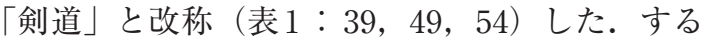
と, 師範校長会は, 文部省の諮問が「撃剣」だけ （表1：51）だったにもかかわらず，諮問の「撃 剣」を「剣道」と書き換え, しかも, 諮問にはな

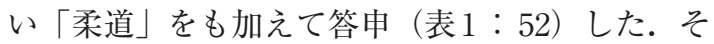
の上，「撃剣」だけを諮問した文部省までもが， この「剣道」「柔道」からなる答申を地方へ通牒 している (表1：53)。これらは，高師の「撃剣」 から「剣道」への改称が，師範系だけでなく，文 部省によっても受入れられたことを意味する。

ところが，文部省は，明治 44 年に「剣道及柔 道」ではなく,「撃剣及柔術」の名称で学校導入 に踏み切った（表 1：57）。普通ならば，高師は， これを承けて「剣道」「柔道」を「撃剣」「柔術」 と改称することになる。

しかし，高師は改称せず，「柔道」「剣道」を使

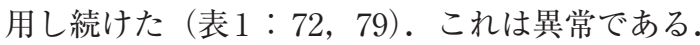
加えて, 同校体操担当教授永井は, 「撃剣」（表 1：44）から「剣道」使用（表 $1 ： 58 ） に$ 転じ, 


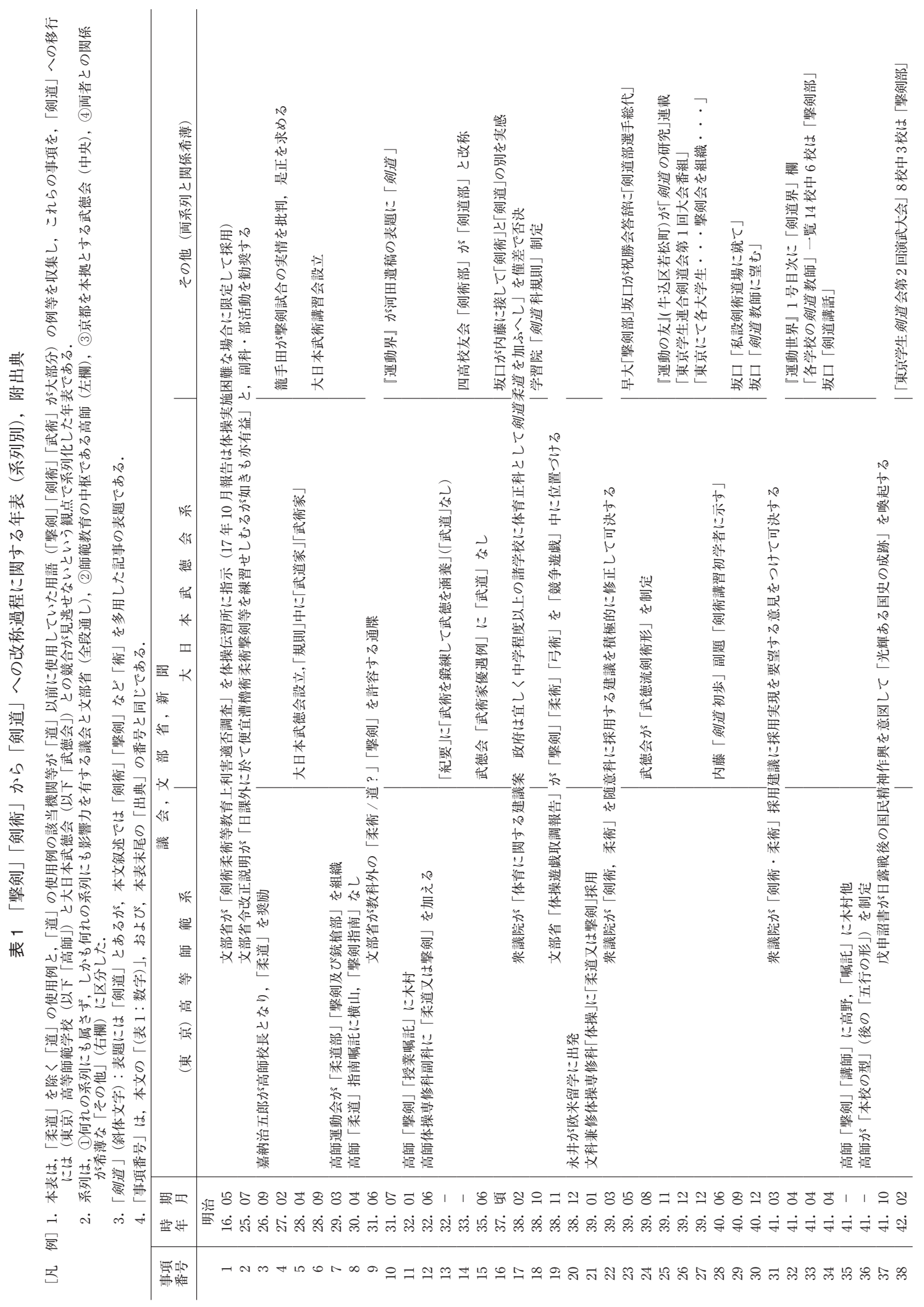




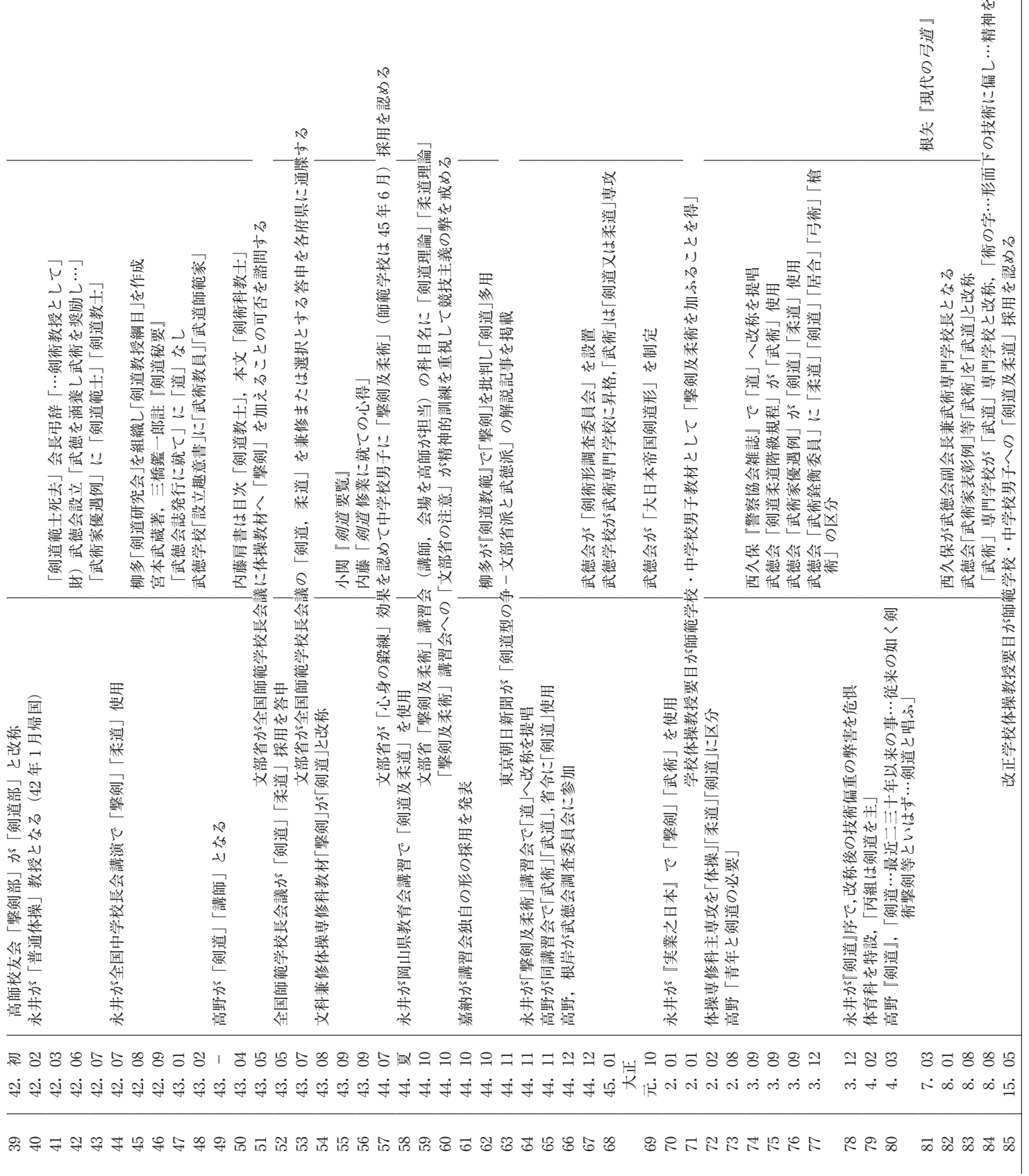




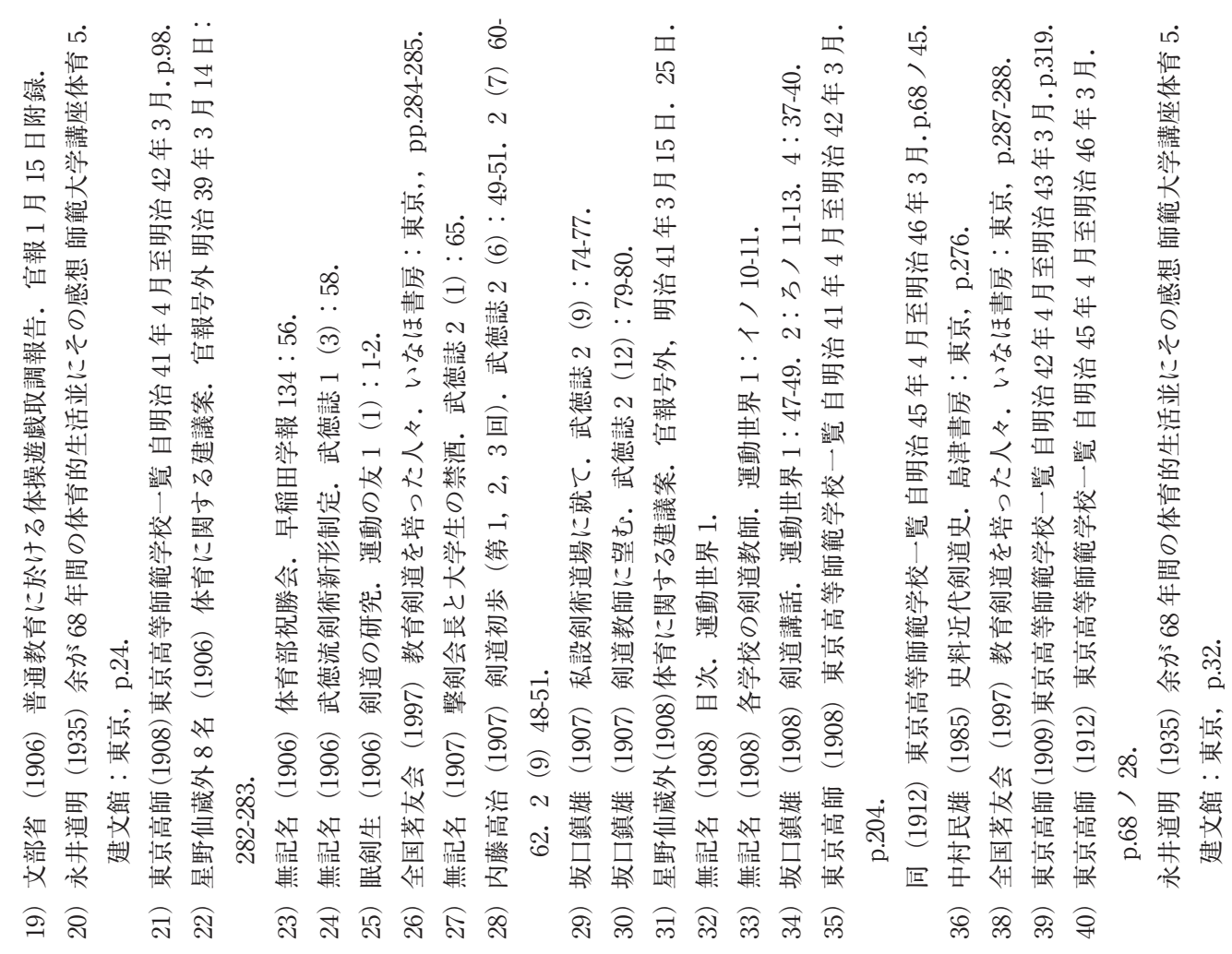

苗

政

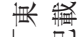

to

您密

續

基齿

呲蕰点

项

政

$\leftarrow 6$

点和

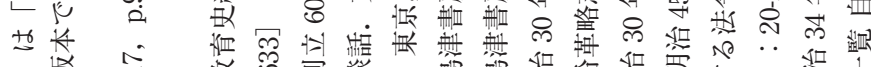

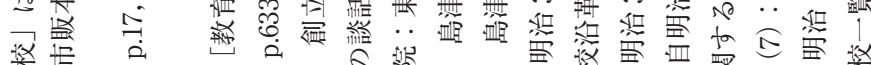

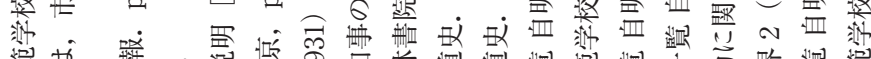

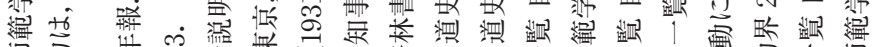

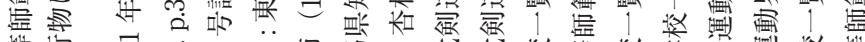

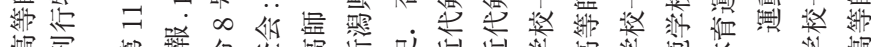

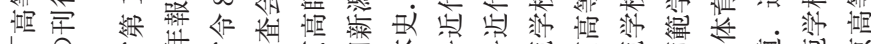

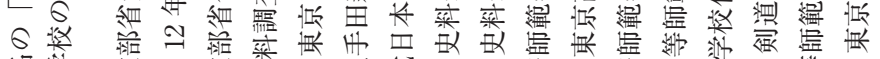

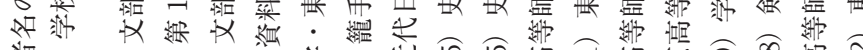

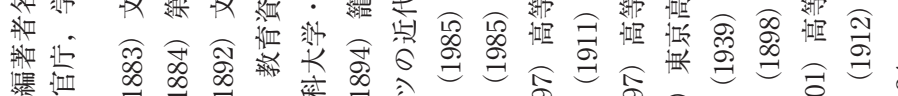

嘈

○ิ

王胥

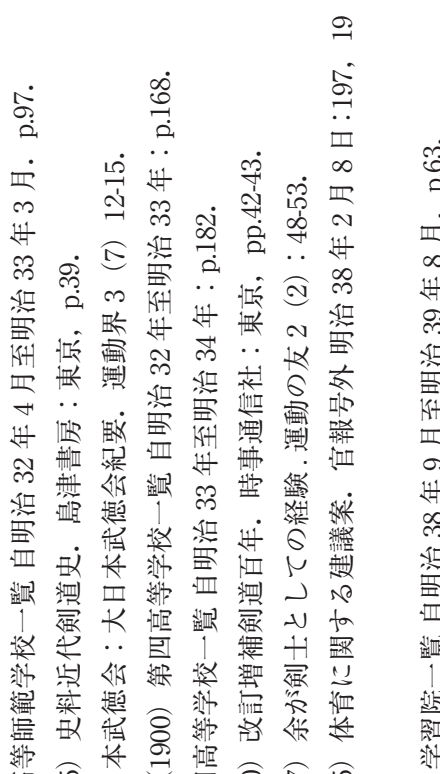

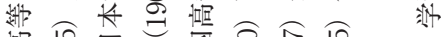

㥊

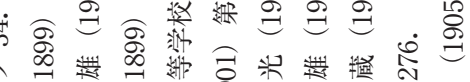

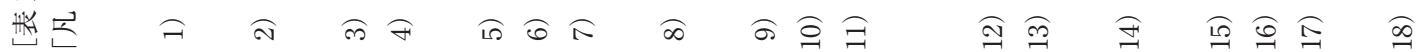




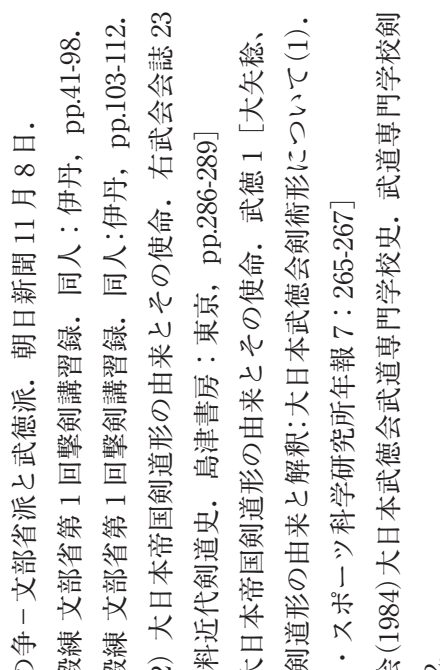

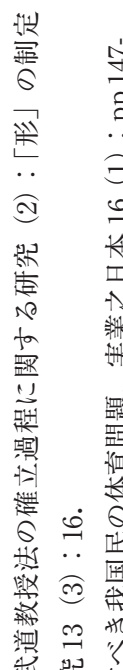

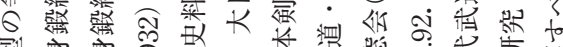

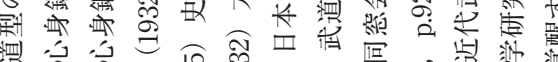

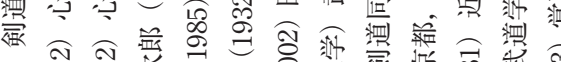
Э

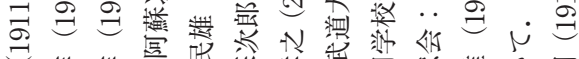

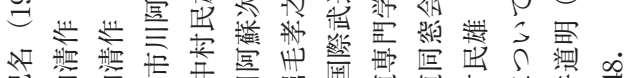

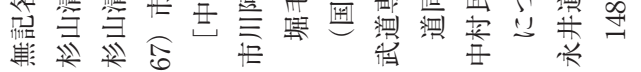

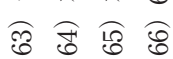

年

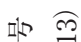

位

仁

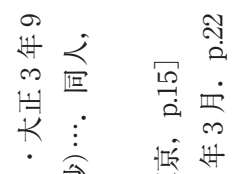

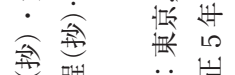

$\infty$ 四器

- … 爽 船

$\stackrel{0}{i}$ 监

…柏㗪然

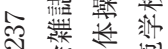

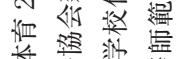

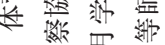

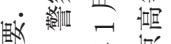

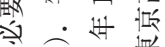

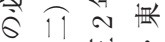

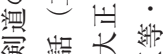

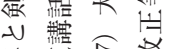

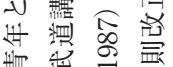

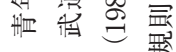

ส

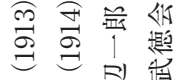

留澴紫茯

齿察

紧

授

111 絀

范悬

地星地

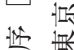

(1)

హิ ڤి

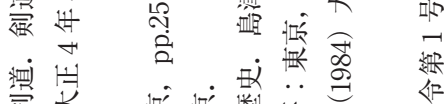

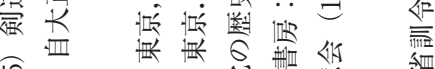

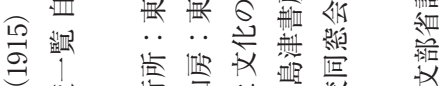

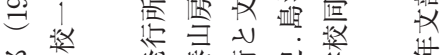

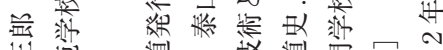

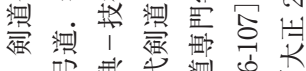

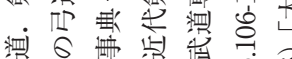

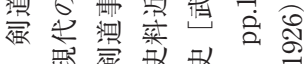

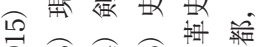

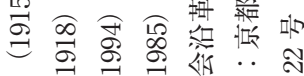

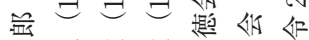

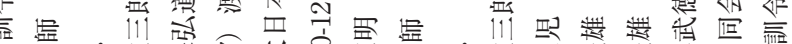

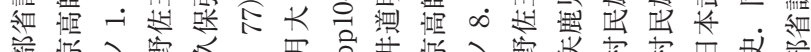

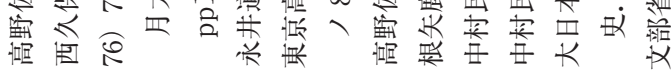
๙ิ

कิ

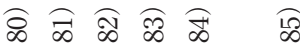

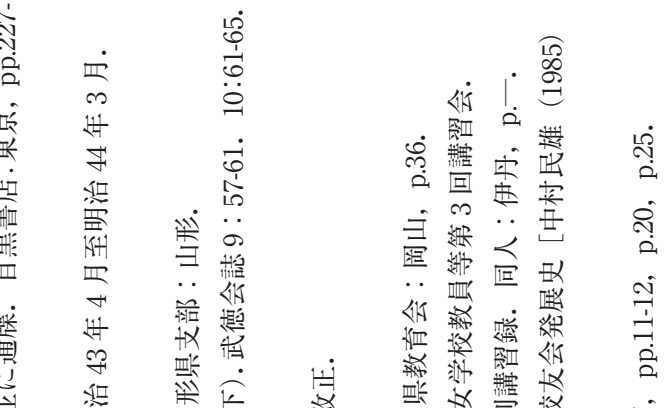

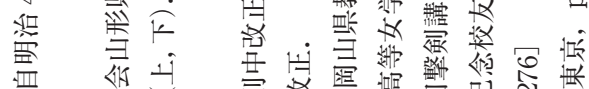

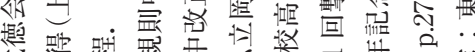

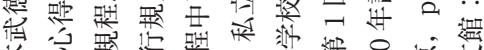

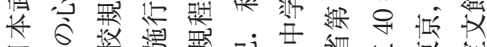

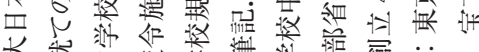

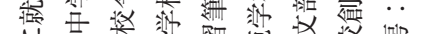

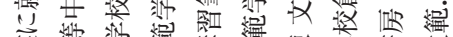

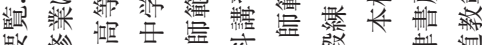

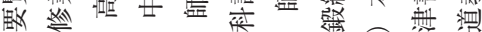

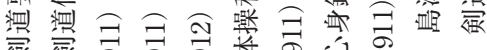

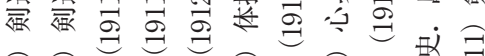
. $\begin{gathered}\hat{\sigma} \\ \sigma\end{gathered}$ $\exists \rightleftharpoons \sqsupseteq$ 只

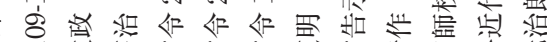

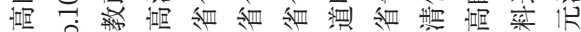

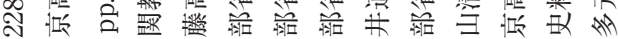

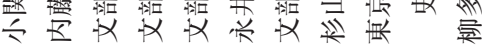

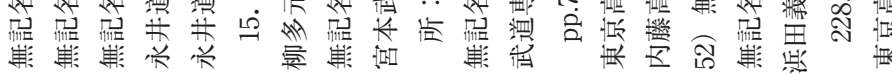

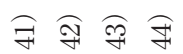

(1) कृ
क्षे ति ति त्र
周合合 

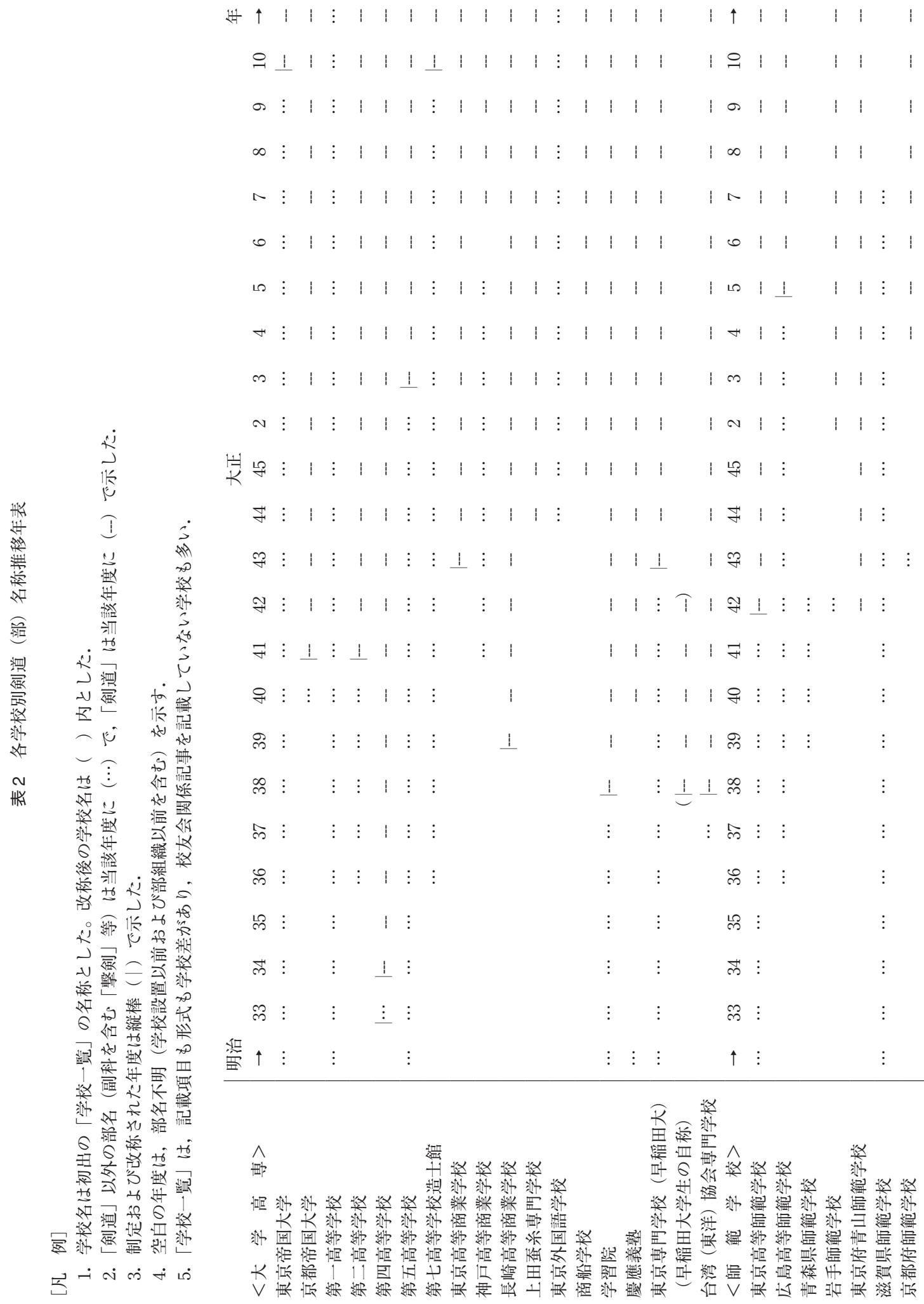


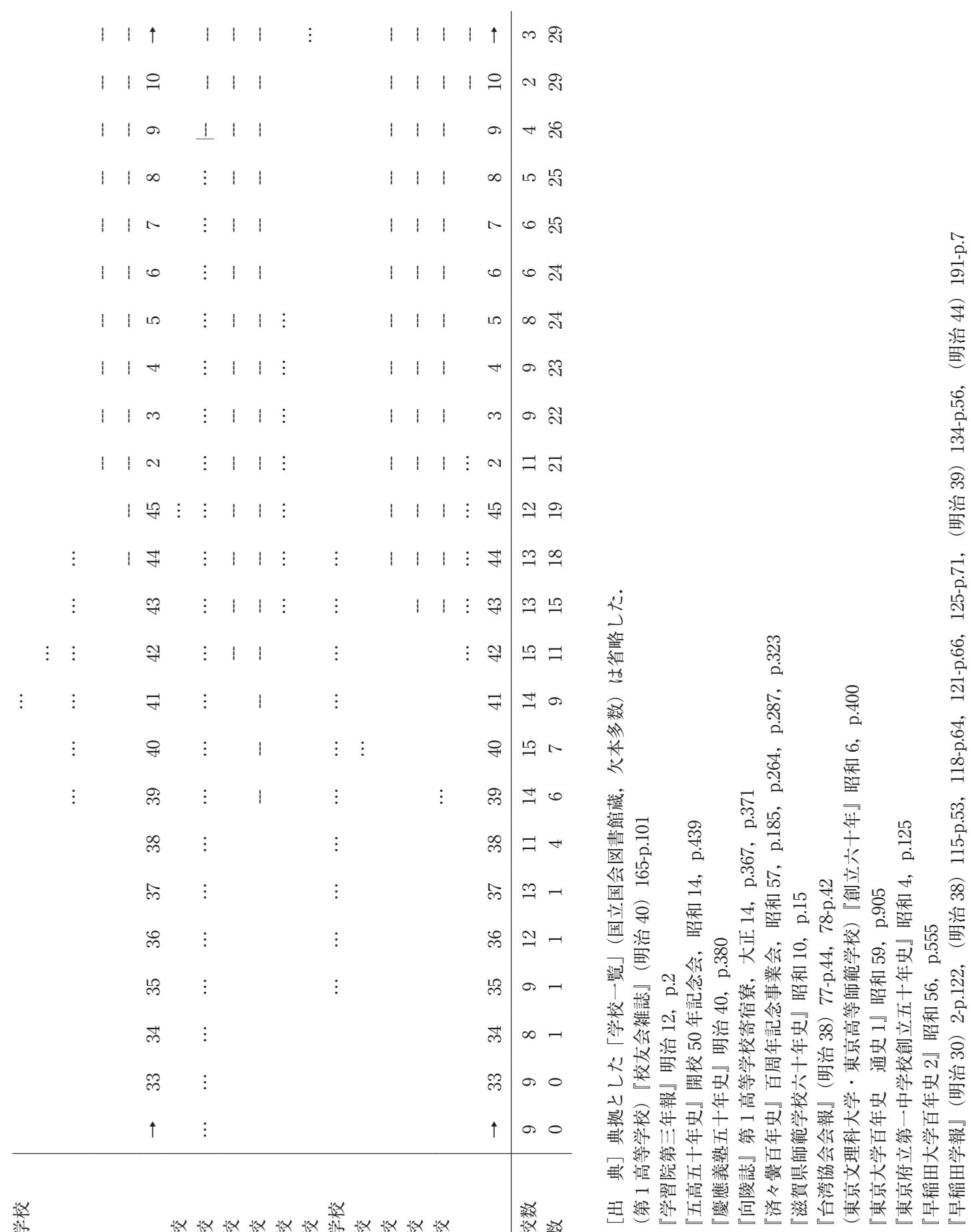

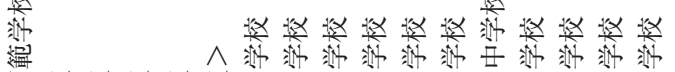

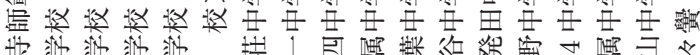

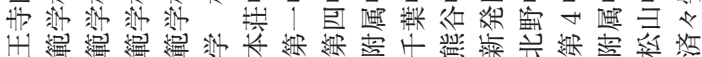

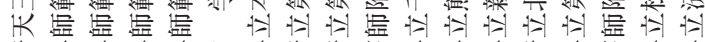

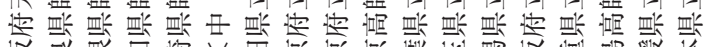

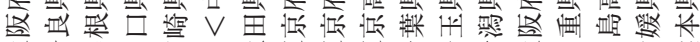
倠 站 粆 鰜 此 眹 灵 鲉 既展

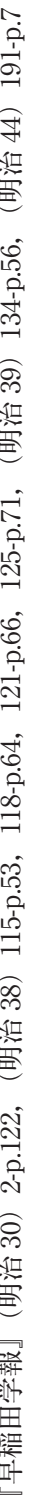


同年文部省講習会において「撃剣及柔術」を「剣 道及柔道」と改称すべきであると提唱した（表 1：64).この経緯からみて, 高師は,「撃剣」を 「剣道」と改称する形での「術」から「道」への 移行に極めて積極的であったと考えられる。

(3)設立当初の「武徳会規則」にある「武術」と 「武道」（表 1：5）の異同は定かでないが，「武術 を鍛練して武徳を涵養」とある「武徳会紀要」 （表1：13）では，一切「道」を用いず，「剣術」 その他すべて「術」を用いた。この武徳会の基本 的概念である「武術」と「武徳」は財団化後も継 承されるから（表 $1 ： 42 ） ，$ 武德会では，「武徳」 とまぎらわしい「武道」，したがって「剣道」の 使用は極力避けていたと考えられる.

また，「中等学校以上の武術教員たるは勿論兼 ねて倫理，歴史等の教員資格をも得て武道師範た るの使命を全ふせしめんとす」（表 1：48）注2） みると, 武徳会では, 「武道」を「武術」の上位 概念に位置づけていたことが分かる。さらに， 「武術家優遇例」が「品行方正」で「精錬証」を 受け，かつ「武德祭演武大会に於て武術を演じた る者」を教士，丁年（成人）後 40 年以上「武術 を鍜錬」した「模範」的な「功労」ある高齢者を 範士として（表 1 ：15）「剣道教士」「剣道範士」 の称号を与えたこと（表 1：43），「剣道」を称号 以外では使用しなかったこと（表 1：41）からみ て,「剣道」が「剣術」だけでは到達できない価 值ある存在であったことが分かる。

したがって，「剣道」と「剣術」とは同義では なかったから，武徳会が「術」から「道」への移 行に積極性を示す筈はなかったと考えられる.

しかし，武徳会機関誌の編集者は，書名や記事 の題名に「剣術」に替えて「剣道」を使用（表 1：28）している（後述）。これは「術」から 「道」への移行という趨勢の反映であろうが，こ れによって，武徳会では，上位概念である「剣道」 と下位概念である「剣術」とが同義であるかのよ うな混乱を呈することになる。

その後, 武徳会では, 高師との学校剣道の形に ついての主導権争い（後述）が発端となって，大 正元年に「剣術形」（表 $1 ： 67$ ) を「剣道形」（表
1：69）に改めた。しかし，「術」から「道」へ の移行には，依然として消極的だったようで（表 1：75，76，77)，「道」が「術」を駆逐する形で, 「術」から「道」への移行が完結する（表 1：83, 84）のは大正 8 年のことである.

(4)早稲田大学「撃剣部」の学生が「剣道部」を 名乗っていた（表 $1 ： 23$. 無記名，1905）ように, 「術」から「道」への移行は東京の大学高専剣道 部員間の関心事（表1：25，26，27，33，38）で, 大会名など（表 $1 ： 26 ， 32 ， 33 ， 38 ） に は 「$ 撃剣」 でなく「剣道」が使用された。「撃剣」と呼ばれ る竹刀術が「剣道」とも呼ばれるようになったの であるから，「術」から「道」への移行は，東京 の学生部員によって, 部名の改称と併行して進展 したと考えられる。

\section{2. 総合的考察}

「術」から「道」への移行について, 表 1 を総 合的に考察すると，以下のことが分かる.

(1)競技主義化した竹刀術である「撃剣」に対す る当初の批判（表 $1 ： 4 ）$ は, 「撃剣」の名称変更 までは視野になかったが，「武徳会」が精神性を 想起させる抽象的名称を採用した（表 $1 ： 5 ） よ$ うに，技術色の濃い「撃剣」よりも，精神性を連 想させる「剣道」（表 1：10，14）への移行に及 んだ。

(2)その中で，日露戦争後に「撃剣」を「剣道」 に置き換えたのは東京の大学高専の学生部員で, 「撃剣部」と「剣道部」が一場に会した竹刀競技 会を「剣道会」（表 $1 ： 26 ， 38 ）$ と称した.

(3)その一人, 早稲田大学部員中の代表格（表

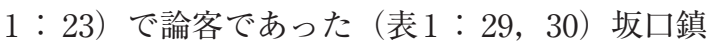
雄は, 卒業後, 明治 41 年に「剣道講話」（表 1 : 34）を発表した。彼の学生時代の経験談によると, 「剣術」に幻滅を感じた彼は，「剣術」の上位概念 に価值を見出し，これを「剣道」と呼んでいる (表 1：16，後述).

(4)学生の「剣道会」に参加していた高師「撃剣 部」は, 明治 42 年に「剣道部」と改称した（表 1：39）。高師内で「柔道」部に遅れを取ってき た「撃剣」部（表 $1 ： 3 ， 7 ， 8 ）$ は，「撃剣」を避 
けて「剣道」を用いる「剣道会」の気運を背景に, 「剣道」部への改称を実現したのであろう。これ を契機に，翌 43 年，高師は正科でも「撃剣」を 「剣道」と改称する（表 $1 ： 49 ， 54 ）$.

(5)したがって，(2)，(3)，(4)を総合すると，明治 42 年の高師での「撃剣」から「剣道」への移行 の論拠に，明治 41 年の坂口「剣道講話」を据え ることも可能となろう.

(6)明治 38 年，議会は「剣道」「柔道」の学校採

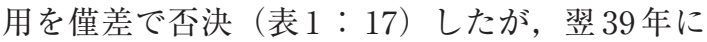

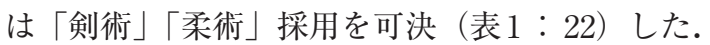
これに呼応するかのように，高師は体操専修科の 「柔道又は撃剣」を副科から正科に格上げし（表 1：21），武徳会は「武徳流剣術形」を制定した (表 1：24).ともに, 剣道の学校導入に不可欠の 施策で, 学校剣道の主導権確保が念頭にあったと 思われる。

(7)高師は，その後明治 41 年に「撃剣」担当教 員を増強（表 1：35）し，高師の形を制定（表 1：36）した．後者は武徳会の形と競合するが, 学校教育の総本山を自認する官の高師が，学校剣 道の主導を決心したのは当然である。そのため, 高師は，教材名でも既存の「撃剣」「剣術」を捨 てて，学生が関心を示す呼称である「剣道」での

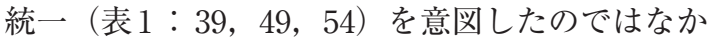
ろうか.

(8)これに対し，民間団体とはいえ，武道界の全 国統一に先鞭をつけてきた武徳会も，遅ればせな がら指導者養成に着手し，明治 43 年に京都府認 可で設立した武德学校（表 1：48）を45年に文 部省認可の武術専門学校に昇格させた（表 1 ： $68)$.

(9)この高師と武徳会の主導権争いが顕在化する のは，嘉納高師校長が，明治 44 年「撃剣及柔術」

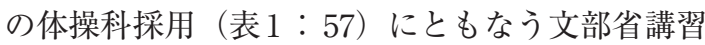
会に，独自の形を採用すると発言したこと（表 1：61）である。この発言は，武徳会の「剣術形」 を否定することを意味する，当然，両者の決定的 対立を招き，「形の争」（表 $1 ： 63 ）$ として顕在化 したのである。

(10)ちろん，文部省講習会を掌握した高師の優
位は動かない。そこで，武徳会は，「剣術形」の 再調査（表 $1 ： 67 ） に$ 高師の参加を求めて（表 1：66）妥協を意図した。しかし，その結末は, 実のみならず，「剣術」の名まで高師の「剣道」 （表1：69）に譲らねばならなかった。

(11)この過程で「撃剣」を「剣道」と改称すべき 理由を述べたのは，明治 44 年文部省講習会で 「体育理論」を講じた高師普通体操担当教授永井

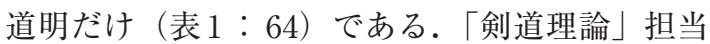
の根岸信五郎と，事実上「剣道理論」を講じた高 野佐三郎は，「術」と「道」を別の概念と捉えて いる（表1：65. 木下，2005）。したがって，「撃 剣」から「剣道」への移行の手がかりは，永井以 外には考えられない。彼の改称理由表明の場が文 部省講習会であったことを考えれば，文部省が 「撃剣及柔術」を教材名に採用した（表 $1 ： 57$ ) にも拘わらず，「剣道」「柔道」が学校現場へ伝搬 定着していくことは疑う余地がない，

(12)この講習会で，高野は省令の「撃剣」に言及 する時だけ「剣道」を口にした。しかし，講義で は，「剣道」を使わず，「武道」と「武術」を目的 と方法の関係で用いた。したがって，両者は基本 不可欠の別概念（表 1：65）であった（木下， 2005)。ところが，高野は，数年後には「剣道」 だけを用い，「術」と「道」に言及しなくなる (表 1：73，80）。高野は永井に追随したのである. 13西久保弘道は，高野が「剣道」だけを使うよ うになったのと同じ頃，「武術」から「武道」へ の改称を提唱し（表 $1 ： 74 ）$ ，やがて「剣道形」 制定で威信を失墜していた武徳会再建に際し（表 $1 ： 82)$,「術」と「道」が混在していた武徳会 （表1：75，76，77）を「道」で統一する役割を 果たした（表 $1 ： 83 ， 84 ）$.

以上からみて,「術」から「道」への移行過程 で「道」を採用する理由に言及した人物は，坂口， 永井，西久保の 3 名だけであると考える。

もちろん，抽出した資料中には，題名に「剣道」 を加えた雑誌記事や「剣道」を冠した図書もある。 そこで，つぎに，この 3 名を考察する前に，これ らの図書と雑誌を検討する. 


\section{III「剣道」論文の用語と用法}

\section{1. 編集者の場合}

明治 31 年の「剣道」（表 1：10）の前書きに 「剣道の振興に最も力を尽くされたる, 故従三位 子爵河田景興氏の, 剣術の無形的に必要なること を述べられたるもの」とあるように，この時期に 書名や杂隹誌記事の題名に「撃剣」「剣術」でなく 「剣道」を用いた例（表 1：25，32，81）は多い。

その中には, 雑誌表紙の目次に竹刀術の名辞を 「撃剣」「剣術」「剣道」から択一して「剣道界」 欄を設けたり（表 $1 ： 32 ）$ ，編集者が「撃剣部」 教師を「剣道教師」と書き直したり（表 $1 ： 33 ）$, あるいは，本文の著者肩書の「剣術科教士」が目 次では「剣道教士」とされた例（表 $1 ： 50 ）$ 等が 見られる。これらは，当時の雑誌編集者が読者の 関心を惹くために工夫した表紙記載の常套手段で あった。

しかし, 内藤高治の場合, 目次題名と本文主題 は「剣道初歩」であるが, 本文副題には「剣術講 習初学者に示す」とある（表 $1 ： 28 ） 。$ 文中では, 「西洋剣術」と対比して「我朝剣道の基因は $\cdots$ 遊 戯に初まりたるに非ず」（p. 49）と「剣道」を用 いた他は，すべて「剣術」である。これは，編集 者が，著者内藤の題名を副題に下げて，「剣道初 歩」を主題に書き加えたからであろう。

内藤の「剣道修業に就ての心得」(表 $1 ： 56$ ) の場合も，1回だけの「剣道講習」以外は，全て 「剣術」「剣法」であるから，編集者が「剣術修業」 を「剣道修業」に書き直したことは明らかである。

「宮本武蔵著, 三橋鑑一郎註」とある『剣道秘 要』（表1：46）は，書名に「剣道」を用いた最 初の図書である。三橋は明治 42 年 3 月死去であ るから，「剣道」使用の同年 9 月付「例言」も， 書名の「剣道」も，編集者によるものであろう。

なお，「(剣) 術」から「(剣) 道」への移行は, 大正 7 年には弓術界にも波及した。書名に「弓道」 を用いた最初は『現代の弓道』（表1：81）であ るが，その目次には，「弓道」はなく，すべて 「弓術」を用いている。これは, 出版社が書名に
「弓道」を先取りしたことを意味する。

以上のように, 明治 38 年日露戦争の大勢が決 した頃から本格化する「(剣) 術」から「(剣) 道」 への移行は, 編集者によって, すでに明治 30 年 頃から先取りされていたのである。これは，大正 4 年の高野佐三郎の「剣道」は「最近二三十年以 来の事」という回顧（表1：80）と一致する.

\section{2. 柳多元治郎の場合}

柳多の明治 42 年「剣道教授綱目」(表 $1 ： 45$ ) は「竹刀木刀は武士の魂とする処の日本刀に模造 せしものにして道具は武士道を錬磨する唯一の武 器」と述べて, 竹刀木刀を用いる教授の目的を 「其精神を鍛錬し其の身体を健全にし本邦特有の 武士道を涵養して大和民族の本分を尽くすにあ り」とする，柳多は，竹刀木刀を用いる教授の目 的に武士道的精神を揭げて，「剣術」ではなく 「剣道」を冠したのである. 竹刀木刀の操法を教 授するのであるから，その上達を度外視した教授 はあり得ない。当然, 操法上達の程度を知る「試 合」と「審判」の指針が示される。これは技術の 問題であるから，その主語には，目的に技術を揭 げない「剣道」よりも，技術を謳った「剣術」が ふさわしい。ところが, 柳多は,「剣術」を用い ずに，「試合中目前の勝負のみを争ひ卑劣の挙動 を為し武人の体面を涜す可らず」，「精神修養に重 きを置き技術上の勝敗は成る可く決せざる方可と す」と, 精神を強調して技術主義に陥ることを戒 める.

柳多は，竹刀木刀を用いる教授の技術主義的弊 害を是正するため，技術的表現である「剣術」の 使用を避けて, 武士道的精神を強調する語感の 「剣道」に置き換えたのである。

しかし, 彼は,「撃剣」「剣術」を「剣道」に置 き換えた理由に一言も触れていない。

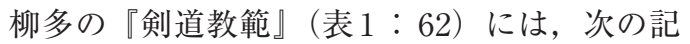
述がある。

案ずるに撃剣の文字は，剣道諸流の伝書の中 に見へず, 維新以前は普く剣法, 剣道, 剣術 の称呼を以てせり, 蓋し興行を創むるに際し, 剣道の名称を憚り改称せしものならんか 
(p. 12)

現今青年の演ずる所の撃剣に至りては，真剣

に違ふ所の長竹刀を振り毉し跳び廻るを常と

す，何たる児戯ぞ，之れを以て本邦固有の武

術と為すは誤れるの甚しく $\cdots$ (p. 20)

維新後の蘋盛を買うような竹刀競技に「撃剣」 を充てたのであるから，柳多が「撃剣」を忌避し たことは分かる。しかし，「剣術」を避けた理由 にはならない。

ともかく，柳多は，理由を述べずに，感覚的に 「(剣) 術」に替えて「(剣) 道」を用いた最初の 人物ということになる。

\section{3. 小関教政の場合}

明治 43 年に「武徳会山形県支部剣道教士」の

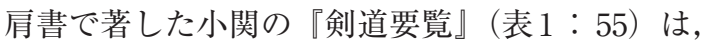
「剣道」を冠した2番目の図書である。

小関は，緒言の戊申詔書（表 $1 ： 37 ）$ を模した 「我が神聖なる武道の成跡」（p. 2) という時代を 意識した総論的叙述では「剣道」「武道」を用い る.しかし，「道」が出て来るのは，本論最初の 見出しの「剣道大意」迄である。その書き出しの 「夫れ兵法は心の妙徳也」（p. 1）以降は，「剣道」 ではなく「兵法」を用いているし，「試合の事」 （p.15一）からは，「柔道と剣術」（p. 36）を含め て，すべて「剣術」を使用している。また，「武 道の蓡奥を極めんには道理に暗くては技術に長ず るも其功なし」（p. 15）と，「術」だけでは「道」 に到達できないことを指摘する。

したがって，小関が「術」と「道」とを次元の 異なる非連続の別概念と認識していたことは明ら かであるから，小関は「術」から「道」への移行 と無関係であったと考えられる。

以上から，以下の 2 点を指摘できる。

(1)「(剣) 術」から「(剣) 道」への移行は，す でに明治 30 年頃から編集者によって始まり，本 文中で使用される主な用語如何に拘わらず，題名 に「剣道」を採用した例は多い。柳多の場合も， 編集者と同様の認識で「術」から「道」への改称 を実践した。しかし，彼らからは，「術」から 「道」への改称の論理を見出すことが出来ない。
(2)小関の場合は，移行の趨勢を意識して「道」 を使用したが，「術」の概念をも必要とした。し たがって, 彼が「術」から「道」への移行に関与 したとは考えられない。

最後に, 坂口, 永井の「剣道」, 西久保の「武 道」採用理由を明らかにし，「術」から「道」へ の移行に占める 3 人の意義について考察する.

\section{IV「剣道」提唱者と提唱理由}

\section{1. 坂口鎮雄の場合}

坂口は, 明治 37 年（推定）入学の早稲田大学 「撃剣部」主力部員（無記名，1905。無記名, 1907）で，「剣道部」を自称していた（表 $1 ： 23$ )。 執筆者や発行所（表1：25）放考えて，早稲田 色の濃い『運動之友』に掲載された「余が剣士と しての経験」（表 1：16）によれば，坂口は，明 治 35 年, 武徳会熊本支部の情実人選によって, 熊本県立済々黌卒業を前に，京都本部での修業の 機会を奪われたことから，信じていた「剣術」界 に疑念を抱くようになった。卒業後，「之を遺恨」 とした父が京都へ出してくれたので，より強い 「剣術」を志して内藤高治（前述）に師事したと ころ, 内藤の「独り剣道に於ける偉人ではなく, 広く漢籍に通じ，孔孟の教へを説き，其の高潔な る品性」に感化されて,「剣術」でなく「剣道」 を目指すべきであると自覚したという。

坂口は，この内藤への師事の話を境に，文中で の用語を「剣術」から「剣道」へ替え,「剣道に 志す者」の要件を，次のように指摘する.

第一高潔なる品性を持つ可き事であります. 又敏活なる挙動をなす可き人を要し，物に当 りて益々猛進す可き勇気ある人を要します。 (p. 52)

坂口は，「剣道」を，竹刀術という可視的側面 である「剣術」と, 品性と敢為の勇気という人格 的側面からなると認識し，「剣道」を「剣術」の 上位概念に位置づけたのである。

彼が「剣道」を標榜していたことは，明治 39 年春の早稲田大学体育部主催優勝各部祝勝会での 答辞で，成文上の「撃剣部」ではなく「剣道部総 
代坂口」と名乗ったこと（表 $1 ： 23 ） に$ 明らかで, 「当大学へ入校し, 学業の傍ら熱心に斯道を研究 しつつありますが, 此の東京の剣道界に於ては, 確かに他地方のものと異なり」（p. 52）には， 「剣術」を含む「剣道」の実現を東京の学生剣道 界に期待していたことが窥える。

明治 39 年末開催の「東京学生連合剣道会第 1 回大会番組」（表 $1 ： 26 ）$ をると, 竹刀試合の 番組と何ら異なるところはないから，この「剣道」 は「撃剣」の読み替えに過ぎず，坂口の標榜する 「剣道」の一部分に過ぎないことになるが，一部 の学校で始まった「剣道部」への改称の趨勢を背 景に, ともかく「剣道」が代表的用語としての座 を認知された最初であると云えよう。

坂口は「私設剣術道場に就て」（表 1：29）で も, 次のように「武道の師」を肯定的文脈, 「武 術教師」を否定的文脈の用語として使い分ける.

今日武道の師となるべきものは単に剣道の技 のみならず多少時代の如何を知り又世界の大 勢に就てもセメテ其一端を看取するの能力を 有し且又普通学理の大体位みには通ぜざるべ からず，吾人は斯道の為め世間往々武術教師 の品性心術に就て将た平常不断の行為に於て 頗る多くの欠点を有するものの比較的少なか らざるを目撃して真に遺憾を感ずるものであ る. (p. 76)

このような「剣道」と「剣術」についての認識 が，「剣道講話」（表 $1 ： 34 ）$ の冒頭での，つぎの ような坂口の「剣道」の定義となったのである.

剣道とは，剣を使用するには如何にすべきや と云ふ方法即ち剣を用ふるの術及び之れを用 ふるには其の人格を如何なる方向に発展せし むべきや，即ち其の徳性は如何と云ふを，教 へ導くにあり.（p. 47）

この定義の後には,「単に剣術と称せば剣を用 ふるの術を修むれば足れりとの感を生じ，又世俗 の撃剣なる語源は…と続く.

したがって，坂口の「剣道」には，「剣術」「撃 剣」と呼ばれる竹刀の技術と「人格」「徳性」「品 性」「勇気」のような人格とが不可欠であったか ら,「剣道」は「剣術」「撃剣」の上位概念であっ
て，「(剣) 術」に替えて「(剣) 道」と改称でき るような同次元の概念ではなかったのである.

したがって，坂口は，可視的な「剣術」にはな い精神性の価值に注目した「剣道」の提唱者では あるが，「剣術」を否定したわけではなく，「剣道」 の一部に「剣術」を認めているのであるから， 「剣術」から「剣道」への移行と関わりのないこ とは明らかである。

\section{2. 永井道明の場合}

高師では，嘉納校長のもとで，まず「柔道」が 地歩を獲得し（表 $1 ： 3$ ）, 遅れて「撃剣」が加わ ったため，常に「柔道」優先であった（表 $1: 7$, 8，12).このため, 内心では武芸の筆頭を自負す る「撃剣」関係者の念頭に,「柔道」と対等の地 位に立ちたい想いがあったことは否めない。

とくに，「柔道」は「柔術」を改称して近代化 に成功している（木下，1970）から，「撃剣」か ら「剣道」への改称は, 高師では「柔道」と比肩 する方便の一つになり得たし，東京の学生間には 「剣道」改称の気運が高まっていたのであるから， 明治 42 年の「撃剣部」の「剣道部」への改称 （表 $1 ： 39 ） ４ 3$ 年の教材名変更（表 $1 ： 49 ， 54 ）$ には，改称理由を説明する必要はなかったと考え られる。

しかし, 文部省が教材名に「撃剣及柔術」を採 用する（表 $1 ： 57 ） と$, 高師は, 師範教育の総本 山の面子から，自校採用の教材名「剣道」「柔道」 の正当性を主張しなければならなくなり，当然，

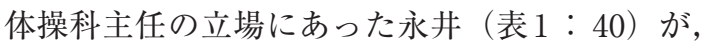
その理論的説明をせざるを得なかった筈である.

以上のような事情を背景に, 明治 42 年には 「撃剣」を用いていた永井（表 $1 ： 44 ）$ が，明治 44 年文部省講習会で担当した講義「体育理論」 （表1：64）中で，文部省が採用した「撃剣」と いう教材名を「剣道」に替えなければならないと 講義したのである.

永井は，その理由として，体育（身体教育）目 的の体操が技術主義化したことへの反省と, 技術 偏重の「撃剣」を正課で実施することに関する危 惧を挙げ，対策として，「撃剣」実施の目的が技 
術でなく精神にあることを視覚的に強調する方便 として，形而下の技術を印象づける表現である 「撃剣」を忌避し，剣をめぐる精神的価值を連想 させる形而上の表現である「剣道」の採用を提起 したのである（木下，2005，p. 23）.

技術偏重の是正と精神重視が本旨であるから， 本来ならば教育内容や教授法の問題として解決す べきであろう。「撃剣」を「剣道」と置き換える ことで, 多少の意識改革は期待できるであろうが, 教材名という看板にキャッチフレーズを採用した 位で，技術偏重の是正と精神重視とが実現すると は到底考えられない。事実, 永井自身も危惧して いた（表1：78）。

したがって，永井の提唱は，「撃剣」から「剣 道」への名辞（記号）の書き換えに過ぎない.

しかし，高師体操科主任永井が，「撃剣及柔術」 採用後の最初の文部省講習会で，「撃剣」に替え て「剣道」と改称せねばならないと講義したこと の学校現場に対する影響力を考えれば，「撃剣」 $「$ (剣) 術」から「(剣) 道」への移行は，永井に よって完全に軌道に乗ったと云える.

\section{3. 西久保弘道の場合}

大正 3 年, 警察練習所における「武道講話 (二)」 （表 1：74）で，西久保警視総監は，「其の名称に 於て，術と云ふ様な語を用ひたとすれば，武と云 ふものは全く術に過ぎないものであると云ふ様な 考が，容易に起こって来る」から，「術といふ言 葉を避けて，特に高尚にして且つ又武道本来の目 的に適合する道」を使うべきであると主張した (p. 13).

西久保は，技術偏重の是正を，「術」の替わり に「道」を用いることに託したのである。

これは，学校を対象とした永井の改称論を警察 の分野，すなわち学校以外へ広げたという意味で の意義はあるものの, 永井の改称論の域を出るも のではない.

しかし, 大正 8 年, 西久保が武徳会の要職に就 く（表 1：82）と，武徳会は「武術」を「武道」 と書き換える（表1：83，84）。「術の字を以てし ては形而下の技術に遍し最も尊重すへき斯道の真
髄たる其の精神を逸するの盧あり」という改称理 由説明は，西久保の改称論そのものである。

したがって，西久保の「(武) 術」から「(武) 道」への改称論は，永井の改称論の複製，二番煎 じに過ぎないけれども, 西久保が武徳会での改称 を実現したことによって，「術」から「道」への 移行は事実上完結したことになる。

\section{結論}

「撃剣」「剣術」から「剣道」への移行の歴史を 整理すると，以下のようになる。

(1)明治 20 年代には始まっていた技術偏重の竹 刀術「撃剣」に対する批判は, 明治 30 年頃にな ると「撃剣」ひいては「剣術」の名辞の忌避とな って，名辞に「剣道」を充てる気運を生じ，日露 戦争後になると, 部名改称の形で「(剣) 術」か ら「(剣) 道」への移行が本格化した.

(2)明治 28 年設立の武德会は，「道」を「術」よ りも価值ある存在と位置づけていたから，「術」 から「道」への移行に主導的役割を果たすことは なかった。

(3)坂口鎮雄は，移行本格化の初期段階で，技術 偏重の可視的な「剣術」の他に，「剣術」だけか らでは得られない精神性の必要を認め, 両者を合 わせた理想を「剣道」と捉えて，この意味での 「剣道」を標榜した。したがって，彼の「剣道」 は「剣術」の上位概念であるから，「術」から 「道」への移行はあり得ない。しかし, 彼が標榜 する「剣道」という名辞は，「撃剣」「剣術」を嫌 忌する学生らにとっては, 時宜を得た名辞であっ た。したがって，彼の「剣道」が日露戦争後の学 生による「剣道部」改称を推進した可能性は捨て きれない。

(4)高師は，学生による「剣道部」への改称の趨 勢下で，明治 42 年に「撃剣」を「剣道」と改称 して, 名辞の面で「柔道」と肩を並べた。したが って，明治 44 年，文部省が「撃剣及柔術」を採 用した時点では, 師範教育の総本山の威信に賭け ても，「柔道」「剣道」に固執しなければならなか った．固執するためには，相当の理由付けが必要 
となる。

(5)この理由付けをしたのが，明治 44 年，最初 の文部省「撃剣及柔術」講習会で，「撃剣」の名 辞を「剣道」に置き換える必要を講義した永井道 明である。講習会の権威を背景とした彼の提唱に よって,「(剣) 術」から「(剣) 道」への移行が 軌道に乗ったのである.

(6) 「(剣) 術」から「(剣) 道」への移行の過程 で見逃せないのは，文部省講習会を機に顕在化し た学校剣道をめぐる高師対武徳会の主導権争いで ある。その結末は, 大正元年, 武徳会「剣術形」 を「剣道形」に書き換えさせた高師の制覇に終わ り, 以後,「術」から「道」への移行を妨げるも のはなくなったのである.

(7)大正 3 年, 西久保弘道提唱の「武術」から 「武道」への移行は, 永井の二番煎じに過ぎない. しかし，これを学校外へ広げた意義は無視できな い。さらに，彼は，大正 8 年，武徳会における 「術」から「道」への移行を完結させた。これに よって, 約 15 年間の長期にわたる「(剣) 術」か ら「(剣) 道」への移行は, 事実上の終止符を打 たれたのである。

8したがって,「術」から「道」への移行過程 で最も重要な役割を果たしたのは，永井による明 治 44 年の「撃剣」に替えての「剣道」の提唱で あり, 西久保に認められる意義は, 移行に終止符 を打ったことであると結論する。

9加えて,「(剣) 術」から「(剣) 道」への移 行が, 単なる名辞の変更に止まって, 竹刀術その ものの変革を伴わなかったことが, その後の現在 に至る精神重視を建前に競技主義を本音とする 「剣道」の出発点であったこと, 坂口が描いた $「$ (剣) 術」と「(剣) 道」との関係での，実をと もなう「(剣) 道」への移行ではなかったことを 指摘したい。

\section{注}

注1）「(表 1：2)」は，表1の事項番号 2 に照応する ことを示す. その出典は, [表1. 出典] (pp. 3839）に同一番号で示した. 以下同じ.

注 2 ) 明治 43 年 1 月付頒布「武徳学校設立趣意」(武

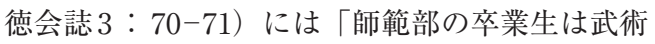
の教師たるの外学科に於ても中等教育の教師た る資格を得さしめんとす」とある。

\section{文献}

井上正孝（1986）剣道はこう学べ：その理論と実際.

玉川大学出版部：東京, pp. 14-16.

木下秀明（1965）大日本武徳会：その前近代性と近

代性. 体育の科学，15（11）：643-645.

木下秀明（1970） スポーツの近代日本史. 杏林書

院: 東京, pp. 32-33.

木下秀明（2005）「撃剣」「剣術」から「剣道」への

移行過程に関する検討：『文部省第 1 回撃剣講習会』

の分析. 体育学研究, 50 (3) : 271 .

無記名（1905）剣道部近事. 早稲田学報, 118：64.

無記名（1907）早稲田大学坂口鎮雄君と早稲田中学

高橋利和君の立合. 運動之友, 2(2)：口絵.

中村民雄（1985）史料近代剣道史. 島津書房：東京.

中村民雄（1994）剣道事典：技術と文化の歴史. 島

津書房：東京, pp. 13-14.

中村民雄（2003）近代剣道小史：近代剣道書選集別

冊解説. 本の友社 : 東京, p. 15.

杉山清作 (1912) 心身鍛練 文部省第 1 回撃剣講習録.

杉山清作：埼玉県児玉郡永幡村, p. 一.

早稲田大学史編纂所（1981）早稲田大学百年史 2. 早

稲田大学：東京, p. 562 .

$\left(\begin{array}{l}\text { 平成 } 17 \text { 年 } 3 \text { 月 } 9 \text { 日受付 } \\ \text { 平成 } 17 \text { 年 } 6 \text { 月 } 25 \text { 日受理 }\end{array}\right)$ 